\title{
Science board one answer to NRC's mounting problems
}

Washington

THE US Nuclear Regulatory Commission (NRC) seems to have a unique ability to infuriate its critics. The latest brouhaha came last month when it granted permis sion to the Tennessee Valley Authority (TVA) to restart the Sequoyah 2 nuclear power plant, closed since 1985 because of questions about its safety performance

The outcry that followed might have been predicted. At the time of the decision, NRC was still investigating Steven White, TVA Manager of Nuclear Power, for lying to officials about safety matters at Sequoyah 2 and other nuclear plants. For its critics, this was further proof that NRC was incapable of making reasonable decisions

There is no shortage of examples of regulatory problems with which NRC must contend. A report by the Critical Mass Energy Project - a public interest organization started by Ralph Nader - says that by March 1988 NRC had received reports of some 2,810 'mishaps' at nuclear power plants in 1987 . Kenneth Boley, one of the report's authors, says examples of NRC's failure to conduct thorough safety reviews are legion and that a particularly egregious example is the South Texas Nuclear Project. He claims NRC reviewed only a few of the 400 safety allegations brought against the South Texas Nuclear Project before granting it an operating licence last month.

A report of a subcommittee of the House of Representatives Committee on Interior and Insular Affairs is at least as critical. The report, NRC Coziness with Industry, argues that the agency fails to keep an "arms-length regulatory posture with the commercial nuclear power industry".

But Carl Goldstein of the US Committee on Energy Awareness, an industry lobby group, says NRC is an effective regulator, capable of taking tough action when necessary. If anything, the industry has been critical of NRC for being overzealous in its regulatory actions. But he agrees that the entire regulatory system needs changing, and NRC is coping the best it can in the circumstances

NRC suffers from organizational problems that detract from its effectiveness. A five-member commission must approve all decisions, adding time to the decisionmaking process. Lando Zech, the present chairman, agrees that the current system is unwieldy, but he quickly adds that NRC "is doing an excellent job of assuring protection of public health and safety within the current structure"

For years there have been calls to replace the commission with a single administrator, and now they seem to be heard. The House Interior Committee is holding hearings on legislation that would create a single NRC administrator, and similar legislation has been introduced in the Senate.

But there are political considerations that may scuttle any legislation this year. Democrats are loath to pass a bill that would give a lame-duck President Reagan the authority to appoint an administrator Republicans fear that a Democratic president might install an administrator unfriendly to the nuclear industry. Certainly Massachusetts Governor Michael Dukakis, front-runner in the race for the Democratic presidential nomination, has not been cordial towards the nuclear power plants providing electricity for his state.

A 3-2 majority, including Zech, in the current commission favours a move to a single administrator. But Zech is not enthusiastic about congressional proposals for an independent science board to review NRC's actions. He would favour a

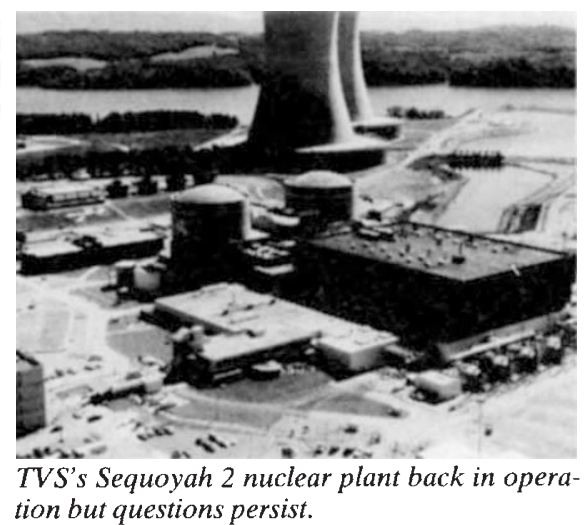

science board that reported to a single administrator, but rejects an independent board that would have authority to make decisions but would not take responsibility for them

Supporters of an independent science board say it would be a valuable asset to NRC. Physics professor Harold Lewis of the University of California at Santa Barbara feels that a strong independent board could help NRC take difficult decisions. NRC already has an Advisory Committee on Reactor Safety, but Lewis, a member of that body, says it has been too narrowly focused on technical issues to provide the kind of thorough scientific overview that is needed.

Congressional support for an independent science board is only luke-warm. The Department of Energy has established an independent committee to watch over the activities of its nuclear reactors, and the fortunes of that body will no doubt influence opinion about a similar body for NRC.

\section{Magnox costs trouble CEGB}

\section{Bristol}

THE future of Britain's eleven Magnox nuclear power stations seems increasingly in doubt following stringent safety requirements imposed on two of the oldest stations as part of a condition of their continuing operation beyond their expected safe operating lives. The Nuclear Installations Inspectorate (NII), a branch of the state-financed Health and Safety Executive, has published its findings in a longterm safety review of the Magnox power station at Berkeley, near Bristol. Last July, a similar report was prepared for the Bradwell Magnox station in Essex.

A Magnox reactor is gas-cooled and fuelled by uranium bars contained within magnesium alloy ('Magnox') cans, with graphite moderator. The reactor core is mounted within a cylindrical mild-steel pressure vessel housed in a concrete biological shield of minimum thickness 8 feet. The Berkeley station has two reactors, each capable of generating 137.5 MW of electricity. Both Bradwell and Berkeley were commissioned in 1962 , with expected useful lives of 20 to 25 years.

When the state-owned Central Electricity General Board (CEGB) indicated that it wished to continue to operate the stations beyond their originally estimated lifespan, it agreed to review the safety of each station after 20 years. In its report on Bradwell, the NII accepted that no immediate danger was presented by the continued operation of the reactors, but listed 17 key requirements that the CEGB would have to meet in order to be allowed to run the station until 1992. The verdict on Berkeley was similar, and the cost to the CEGB of fulfilling the requirements is estimated at $£ 4$ million per station.

Berkeley is at present operating at reduced pressure levels because of defects in welds in parts of the ducts that carry the coolant. Although the NII is satisfied that the ductwork is safe for another two years, it wants the CEGB to demonstrate the ductwork's integrity until 1992 by ultrasonic data. The CEGB, whose chairman Lord Marshall has likened the NII to a "nagging wife", has yet to decide whether the exercise is economically worthwhile.

With the issue further complicated by the impending privatization of the electricity supply industry and the fact that the Sizewell B pressurized-water reactor station is scheduled for completion by 1994 , when it will be able to produce a relatively huge $1,175 \mathrm{MW}$, the CEGB is expected to let the NII know within the next few months what it intends to do about the two Magnox stations. Their closure seems a distinct possibility.

Simon Hadlington 